\title{
Which Parties Count? - The Effective Number of Parties in the Albanian Party System
}

\author{
Anjeza Xhaferaj \\ $\mathrm{PhD}$ Candidate \\ The European University of Tirana, Albania \\ axhaferaj@uet.edu.al
}

\begin{abstract}
The aim of this paper is to explore and understand the Albanian Party System. The analysis will cover the period from the collapse of the communist regime in 1991 until 2014. It will try to investigate what forces drive the battle of the parties, what cleavages 'divide' society and consequently the party system as well as which are the parties that count the most. in order to assess this, the paper will focus on the parliamentary parties and will relay on various theoretical concepts of the contemporary literature on political parties. First it will draw on Sartori's concept of 'relevance' in order to understand whether all the parliamentary parties over the course of twenty four years of pluralism are important or not and what weight do they have. Then it will use the Laakso \& Taagepera index of the Effective Number of Parties to understand how power is distributed within the parliament.
\end{abstract}

Key words: party system, relevant parties, fragmentation index, polarization, ENP

\section{Introduction}

The party system could be defined as a structure, which enables the competition and cooperation among the political parties. Even though it is a structure, nonetheless it is not always stable. Lipset and Rokkan (1967) contend that this structure is stable and it is created as the result of the social cleavages formed within the society of the Western Europe in the beginning of the 20th century. Their thesis is that these cleavages are frozen; they are created once and for all and that they have determined the interaction among the political parties (competition or cooperation as well as the focus of their political program). Bartolini and Mair (2007) are in the same line. in their seminal work on the European electorate during 1885-1985, they observed that 'in the long term, the bonds which tie electorates into a set of political identities and alignments have demonstrated their resilience' (pp.262).

In this context, one might ask whether the Albanian party system has demonstrated any resilience or not. A stable party system is an indication of stable political parties with stable political identities and programs. On the other hand, the change of the party system is a concept which refers to the changes and development of it features, changes which occurs with the passing of time. Lane and Ersson (1994: 4-5) argues that the party system is measured by the following dimensions:

The number of issues which indicate the number of cleavages in the party system as well as the polarization (the ideological distance between parties);

The Effective Number of Parties and the Index of Fractionalization;

The total volatility: the aggregate change of votes between consecutive elections.

However, even though Lipset and Rokkan (1967) contend that the party system is a contingent of the social cleavages, it is influenced by other factors such as a change in the external environment, a change in economy, a change in the leadership of the party, a change of the electoral formula or even the collapse and change of the political system (Pennings \& Lane, $2005: 4-5)$.

\section{The Institutional Factors and the Party System}

In order to understand the dynamics of the party system, it is important to understand that which are the parties that structure such system, or as Bartolini and Mair question: Which Parties Count? Do we count all parties that contest the elections or only those who are part of the parliament? 'The number of parties' is a difficult concept to measure, because scholars very often do not come to terms how to count parties which have different sizes and different relevance (Webb, 2000: 4-5). 
ISSN 2411-9563 (Print) ISSN 2312-8429 (Online)
European Journal of Social Sciences Education and Research
September-December 2014

Volume 1, Issue 2

Sartori's seminal work on party system has always been a point of reference for scholars of political parties to start their investigation. Sartori does not just count parties, which contest in elections. He does not even count all parties, which have seats in parliament. Sartori considers as important only the parties that compete for government positions because they indicate 'the extent to which political power is fragmented or non-fragmented, dispersed or concentrated' (2005: 106). According to him it is important to count only the relevant parties and 'the relevance of the party is a function not only of the relative distribution of power ... but also, and especially, of its position value, that is , of its positioning along the left-right dimension' (pp.107). Sartori links the relevance of the party with the electoral strength of the party and the electoral strength of the party with its governing potential, or the coalition potential for each party, because '[w]hat really weights in the balance of multipartism is the extent to which a party may be needed as a coalition partner for one or more of the possible governmental majorities. A party may be small but have a strong coalition-bargaining potential. Conversely, a party may be strong and yet lack coalition-bargaining power" (pp.107-108). in order to define the relevance of the party, Sartori suggests that in order to find out whether a party is relevant or not 'we can discount the parties that have neither (i) coalition potential nor (ii) blackmail potential. Conversely, we must count all the parties that have either a governmental relevance in the coalition - forming arena, or a competitive relevance in the oppositional arena (pp.108).

It is clear that the political parties position themselves not only along the left-right dimension, but they focus on issues such as religion, culture or ethnicity. Duverger (1954) observed that the party system is created by the fractionalization and superposition: cleavages do not create pure ideal type models of political parties. According to him there are three dimensions which organize the political parties: clerical vs. anti-clerical; east-west, central planning vs. liberal economy. With the fall of communism the east-west cleavage ceased to exist and the two others are those which shape the party system.

Notwithstanding its relevance, the Duverger's theory reflects merely the cleavages in France and indeed, it has been criticized for being ethno-centric. Other authors, such as Lipset and Rokkan (1976) observed that the western party system is the result of two revolutions: the national revolution and the industrial revolution. The national revolution produced the territorial cleavage, which gave effect to two conflicts: state-church and dominant culture - ethnic/cultural minorities. On the other hand, the industrial revolution produced the functional cleavage, which gave rise to two conflicts: employers employees conflict or capitalist - working class conflict if we have to use a Marxist approach and the urban - rural conflict.

Lijpart (1969) is another scholar who observed the emergence of the consociational democracy which is characterized by a plural society with segmental cleavages and segmental elites which cooperate between each other through consociational structures. According to him the consociational democracy has seven conceptual divisions or cleavages: socioeconomic; religious; cultural - ethic; urban-rural; regime support; foreign policy and post-materialism (1984: 122, 130). Even though Lijphart identified seven dimensions in his seminal book on patterns of democracy in the Western Europe, there was no country where one could find more than 4.5 dimensions, which was the case of France. The rest of the countries had between 1 and 3.5 issue dimensions. These kind of cleavages, which Mair (2008, 155-156) considers as vertical divisions are especially observable in the countries which are characterized by the segmentation and fractionalization of the electorate, which means that only one ore few parties could compete for the votes of certain part of the electorate. Therefore, the differences between the party systems of different countries are determined by the importance and strength of the second most important dimension (i.e. language, religion, ethnicity) which generally superposes over the left-right dimension (socioeconomic cleavage) acknowledged by all.

The common element for all these scholars is that regardless of the identification of the issue dimensions, being those economic, cultural, ethnic or religious, the bottom line is that the party system is shaped by them and it cannot exist as such without their existence. in this context, in order to analyse the Albanian case it is important to find out which cleavage/s structure/s and shape/s the party system. This will help to discover the dimensions of the party system.

Sartori (1974:345) argues that the political parties fail to compete with each other for two systemic reasons. One of them is when they position themselves in different axes. Due to the fact, that they are born as the result of two different cleavages, their electorate of belonging is different and thus there is no risk of electors shifting their preferences in the succeeding elections from one party to the other. The second reason relates to the ideological distance: the greater the distance the less likely they will compete with each other. in this case the political parties are positioned in the same axe but are so far apart from each other, the degree of polarization is so high, so that there is no possibility of votes' transfer between them. This is the case of ethnic parties: they have clear borderlines of electorate and consequently there is no possibility that a votes' transfer might happen (Horowitz, 1985:346). Therefore, when analysing the Albanian case, we will not deal with those political parties, which fail to compete for electorate votes. 
European Journal of Social Sciences Education and Research
September-December 2014

Volume 1, Issue 2

In order to understand that which parties compete and over how many issue dimensions it is important to know which are the parliamentary parties. According to Sartori:

...it does matter how many are the parties. for one thing, the number of parties immediately indicates, albeit roughly, an important feature of the political system: the extent to which the political power is fragmented or non-fragmented, dispersed or concentrated. Likewise, simply by knowing how many parties there are, we are alerted to the number of the possible 'interaction streams' that are involved. ...Since these interactions occur at multiple levels - electoral, parliamentary and governmental - the indication clearly is that the greater the number of parties (that have a say) the greater the complexity and probably the intricacy of the system...Furthermore, and in particular, the tactics of party competition and opposition appear related to the number of parties; and this has, in turn, and important bearing on how governmental coalitions are formed and are able to perform $(2005,106)$.

Therefore it is important to number the parties, but according to Sartori only the relevant parties. The following table gives and overview of the distribution of seats in the Albanian parliament effective first democratic elections in 1991 until 2013.

Table 1: Distribution of Seats in the Albanian Parliament: 1991-2013

\begin{tabular}{|c|c|c|c|c|c|c|c|c|c|c|c|c|c|c|}
\hline $\begin{array}{l}\text { Parties1/ } \\
\text { Election } \\
\text { year }\end{array}$ & $\begin{array}{l}P \\
S\end{array}$ & $\begin{array}{l}P \\
D\end{array}$ & PR & $\begin{array}{l}\text { PS } \\
D\end{array}$ & PBDNJ & LSI & $\begin{array}{l}\text { PDI } \\
\text { U }\end{array}$ & $\begin{array}{l}\mathrm{P} \\
\mathrm{A}\end{array}$ & $\begin{array}{l}\text { PA } \\
\text { D }\end{array}$ & $\begin{array}{l}\text { PD } \\
C\end{array}$ & $\begin{array}{l}\mathrm{PD} \\
\mathrm{R}\end{array}$ & $\begin{array}{l}\text { SM } \\
\mathrm{R}\end{array}$ & SML & $\begin{array}{l}\text { In } \\
\text { d. }\end{array}$ \\
\hline 1991 & $\begin{array}{l}1 \\
7 \\
0 \\
2\end{array}$ & 75 & & & 5 & & & & & & & & & \\
\hline 1992 & \begin{tabular}{|l|}
3 \\
8
\end{tabular} & 92 & 1 & 7 & 2 & & & & & & & & & \\
\hline 1996 & $\begin{array}{l}1 \\
0\end{array}$ & $\begin{array}{l}12 \\
2\end{array}$ & & 3 & 3 & & & & & & & 2 & & \\
\hline 1997 & $\begin{array}{l}1 \\
0 \\
2\end{array}$ & 26 & 1 & 9 & 4 & & & 1 & 2 & 1 & & 8 & 1 & \\
\hline 2001 & $\begin{array}{l}7 \\
3\end{array}$ & 32 & 5 & 4 & 3 & & & 3 & 3 & & 6 & 9 & & 2 \\
\hline 2005 & $\begin{array}{l}4 \\
2\end{array}$ & 56 & 11 & 7 & 2 & 5 & & 4 & 3 & & 4 & 1 & 2 & 1 \\
\hline 2009 & $\begin{array}{l}6 \\
6\end{array}$ & 68 & 1 & & & 4 & 1 & & & & & & & \\
\hline 2013 & $\begin{array}{l}6 \\
6\end{array}$ & 49 & 3 & & 1 & 16 & 4 & & & & & & 1 & \\
\hline
\end{tabular}

The parliament of 1991 had 250 deputies. The number was rapidly decreased to 140 in the succeeding elections, with exception of 1997, when it had 155. It is important to clarify that the table does not contain all the information. in the case

1 PS = Socialist Party; PD= Democratic Party; PR = Republican Party; PSD = Social Democratic Party; PBDNJ= Union of Human Rights Party; LSI = Socialist Movement for Integration; PDIU = Justice, Integration and Unity Party; PA = Agrarian Party; PAD = Democratic Alliance Party; PDK =Democristian Party; PDR = New Democratic Party; SPR = Small Parties on the Right; $S P L=S m a l l$ Parties on the Left; Ind = Independent Candidates.

2 in the 1991 elections, the winner was the Party of Labour of Albania. in the party congress held in June of the same year, the party changed its name to the Socialist Party of Albania. The party won 169 seats in the first elections, however the table indicates 170 , because herein is calculated the candidate of the Committee of Veterans, because the committee was one of the ancillary organizations of the Party of Labour of Albania. 
ISSN 2411-9563 (Print) ISSN 2312-8429 (Online)
European Journal of Social Sciences Education and Research
September-December 2014

Volume 1, Issue 2

when a political parties has won a seat in parliament only in one set of elections, it is calculated at the column SPR or SPL. Është e rëndësishme të thuhet se tabela e mëposhtme nuk e përmban të gjithë informacionin.

The Socialist Party has won the elections of 1991, 1997, 2001 and 2013 and it has won $68 \%, 65.8 \%, 52.14$ and $7.14 \%$ of the parliamentary seats. The Democratic Party has won the elections of 1992, 1996, 2005 and 2009. It has won 65.7\%, $87.14 \%, 40 \%$ and $48.57 \%$ respectively. As the table clearly indicates, the two parties have been able to create the government without the help of a coalition in 1991, 1992, 1996, 1997 and 2001. While in 2005, 2009 and 2013 they had to be in coalition with other parties in order to form the government.

Based on these data, it looks like the only relevant parties in the Albanian politics during the period 1991-2001 are the Socialist Party and the Democratic Party. It looks like no party had coalition potential or blackmail potential (Sartori, 2005:107-108). Both Socialist and Democratic Party had the majority (over 50\%) of the parliament but they still had invited other smaller parties in the composition of the cabinets. The following table shows the distribution of ministerial portfolios during 1991-2013:

Table 2: Distribution of portfolios: 1991-2013

\begin{tabular}{|l|l|l|l|l|l|l|l|l|}
\hline $\begin{array}{l}\text { Election year/ } \\
\text { Distribution of } \\
\text { portfolios per } \\
\text { party }\end{array}$ & PD & PS & PR & PSD & PBDNJ & LSI & PAA & PAD \\
\hline 1991 & & 191 & & & & & & \\
\hline 19922 & 203 & & 1 & & & & & \\
\hline 19964 & 22 & - & 2 & - & - & - & - & \\
\hline 1997 & - & 13 & - & 2 & 1 & - & 2 & 3 \\
\hline 2001 & - & 17 & - & - & 1 & - & 1 & \\
\hline 2005 & 11 & - & 2 & - & - & - & 1 & \\
\hline 2009 & 9 & - & 1 & - & 1 & 3 & - & \\
\hline 2013 & - & 15 & - & - & - & 6 & - & \\
\hline
\end{tabular}

1 Zyhdi Pepa and Vilson Ahmeti are independent minsters, but proposed by the Party of Labour (later Socialist Party), therefore are included at the figures of Party of Labour.

2 The figures of 1992 represent the distribution of portfolios only for the first Government composition headed by Prime-minister Aleksander Meksi which exercised its activity during the period 13 April $1992-6$ August 1993. Following the dissolution of this government there are composed two other Meksi Governments which have lasted until the end of the legislature (1996). However, these two other Meksi Government are not part of this study, because the purpose of the study is to evaluate whether there is a relation between the electoral system and coalition governments. The last two Meksi Governments are created as a result of party splits, creation of new parties, dissolution of coalitions, expulsion of elite members from Democratic Party for non-obedience and other similar phenomena which have characterized the post-communist countries especially in the first decade after the collapse of the communist regime. Therefore, they are the product of circumstances and factors that are not related to the electoral system, but rather to the transition process, which has affected all the post-communist countries and Albania among them.

3 The figure includes also the ministers Abdyl Xhaja and Kudret Cela who even though are listed independent ministers, are in fact proposed by the Democratic Party. Furthermore, Abdyl Xhaja has been part of the candidates for MP-s proposed by the Democratic Party in the elections of 1996 and 1997, while Kudret Cela has been part of the candidates for the MP's list of Democratic Party in the general elections of 1996. This is considered a sufficient argument to understand their political affiliation. Furthermore, within these figures are calculated also post at ministerial level such as: General Secretary (Vullnet Ademi), Head of Committee of Science and Technology (Maksim Konomi), Head of Control Commission (Blerim Cela) dhe Head of the Committee of Victims of Communism (Eduart Ypi).

4 Herein are calculated the Secretaries of State, who because of being political positions are considered as part of the Ministerial Cabinet. 
The presence of the smaller parties is due to two factors. The first is the constitutional condition to approve laws with qualitative majority voting. Therefore, a simple majority of $50 \%+1$ was not sufficient. The Albanian Constitution has stipulated that in order to approve important laws and to elect the president of the Republic, it is needed the approval of the $3 / 5$ of the total number of deputies (84 deputies) (Article 81, 87)1. However, Table 1 shows that in the elections of 1992, 1996 and 1997 the winners (respectively DP, DP and SP) got more than 3/5 of the seats in parliament and therefore had no need to form coalitions government. Therefore, we may conclude that until 1997, the small parties were indeed small and their presence had not effect in the parliamentary activity of the winning party as well as on the cabinet composition. The presence of Republican Party ( in coalition with Democratic Party) and that of the Social-Democratic Party and Union of Human Rights Party (in coalition with Socialist Party) could be explained with the necessity that the winner parties had to create an image of all encompassing, so as to have a greater legitimacy in the eyes of the international community.

The history takes another path after the elections of 1997. Effective elections of 2001, none of the 'big' parties have been able to receive qualifying majority or even a simple majority. in these circumstances, it was important to have coalition partners. But which are the relevant parties? The 'big' parties have chosen themselves these coalition parties. This was enabled by the electoral formula. During the period 1992-2005, in Albania are organized five general elections, which are organized according to the principles of the mix electoral system : $100 \mathrm{MPs}$ were elected directly single member districts according to the First Past the Post formula, and 40 were elected indirectly from party lists in a proportional manner (Albania Constitution, Article 64). in the elections of 2001 and 2005 the Socialist and Democratic Party applied the strategic voting, calling to their electorate to vote for the coalition partners in the proportional in exchange for the votes of the coalition parties in the single member districts voting (OSCE Reports, 2001; 2005).

In conclusion we may observe that the existence of the small parties in the second decade after the collapse of the communist regime is enabled by institutional factors such as the Constitutional Laws on voting principles in parliament and the electoral system.

\section{The Effective Number of Parties}

The concept of relevance is somehow ambiguous and therefore it is necessary to use some more specific criteria to establish whether a party is relevant or not. Consequently it is necessary to count the relative size of the party in a party system. in order to do so we will use the Laakso and Taagepera (1979) index which shows the Effective Number of Parties and is calculated as follows:

$\mathrm{N}=1 / \Sigma \mathrm{Si} 2$

where ' $s$ ' is the proportion of the parliamentary seats of party 'i'. If applied such formula in the Albanian case the ENP would be:

Table 3: The Effective Number of Parties

$\begin{array}{ll}\text { Election Year } & \text { ENP } \\ 1991 & 1.81 \\ 1992 & 1.97 \\ 1996 & 1.31 \\ 1997 & 2.14 \\ 2001 & 2.99 \\ 2005 & 3.68 \\ 2009 & 2.21 \\ 2013 & 2.80\end{array}$

1 This has been valid until the 2008 when the Constitution was amended and the qualitative majority was no further needed. 
But how to interpret the ENP. Siaroff (2000) has compiled the following scheme, which helps to understand what type of system does the ENP indicate:

Table 4: Classification of the Party System according to the ENPP

ENPP Classification of party systems

1.92 Two party system

2.56 Two and a half party system

$2.95 \quad$ Moderate multiparty with dominant party

3.17 Moderate multiparty with two main parties

3.69 Moderate multiparty with balance among main parties

3.96 Extreme multiparty with one dominant party

$4.41 \quad$ Extreme multiparty with two main parties

$5.56 \quad$ Extreme multiparty with balance among parties

If we apply such scheme to the Albanian context and attempt to match it with the distribution of seats given at Table 1 , then we would have:

Table 5: Albania Party System Scheme

\begin{tabular}{|c|c|c|c|}
\hline Election Year & ENP & Party System (Siaroff scheme) & Party System \\
\hline & & & Albania Case \\
\hline 1991 & 1.81 & Two Party System & Two Party System \\
\hline 1992 & 1.97 & Two Party System & Two Party System \\
\hline 1996 & 1.31 & Two Party System with one dominant party & $\begin{array}{l}\text { Two Party System with one dominant } \\
\text { party }\end{array}$ \\
\hline 1997 & 2.14 & $\begin{array}{l}\text { Between Two Party and Two and a half } \\
\text { Party System }\end{array}$ & Two Party System \\
\hline 2001 & 2.99 & $\begin{array}{l}\text { Moderate Multiparty with one dominant } \\
\text { party }\end{array}$ & $\begin{array}{l}\text { Moderate Multiparty with one } \\
\text { dominant party }\end{array}$ \\
\hline 2005 & 3.68 & $\begin{array}{l}\text { Moderate Multiparty with balance among } \\
\text { parties }\end{array}$ & $\begin{array}{l}\text { Moderate Multiparty with balance } \\
\text { among main parties }\end{array}$ \\
\hline 2009 & 2.21 & $\begin{array}{l}\text { Between Two Party System and Two and a } \\
\text { half party system }\end{array}$ & Two and a half party system \\
\hline 2013 & 2.80 & $\begin{array}{l}\text { Between Two and a half and Moderate } \\
\text { Multiparty with dominant party }\end{array}$ & Two and a half Party System \\
\hline
\end{tabular}

As one may observe the Siaroff scheme is not always applicable. It does give a wrong perception on structure of the party system especially in 1997, 2005, 2009 and 2013. Furthermore it fails to capture the dynamics of party interactions in 2001, when it is true that it was the Socialist Party predominates with 73 deputies, but it was followed by the Democratic party with 34 and then the rest of the parties had less than ten deputies in parliament and therefore there is no comparison between these parties.

Regardless of its shortcomings the Siaroff scheme helps to understand who are the relevant parties in the Albanian political scene. in addition to the two main parties, the Socialist and the Democratic Party, the Socialist Movement for Integration has appeared to play the kingmaker role in the creation of governmental coalitions in country. 


\section{Conclusion}

The paper sought to explore the dynamics of party interactions in the Albanian political scene. The fall of communist system was followed by the emergence of political parties of different political platforms. The paper attempted to disentangle the various data on the Albanian political parties and to capture any pattern of party competition and coalition.

Duverger (1954), Sartori (2005), Lipset and Rokkan (1967) and Lijphart (1977) are the main scholars which fed into the theoretical framework of this paper the issue dimensions which structure the party system. The common cleavage for all these scholars was the socio-economic one which position the political parties along the left-right spectrum. However, in order to understand how many cleavages organize the political scene in Albania it was important to understand who are the relevant parties. Sartori's concept of relevance was helpful here. in pursuit of which are the relevant parties we found out that in Albania we have only political parties with coalition potential but not with blackmail potential.

The main political parties in the Albanian scene since the collapse of the communist regime are the Democratic Party, the Socialist Party, the Republican Party, the Union for Human Rights Party, the Agrarian Party and the Socialist Movement for Integration. These are the only parties whose members have had ministerial positions in the various governments created since 1991. With exception to the Union for Human Rights Party which represent the Greek minority in country, the other parties have positioned themselves along the left-right dimension. Furthermore, the smaller parties are located in the centre of the political spectrum, which means that only centripetal forces organize the political scene in Albania.

Finally the Siaroff party system classification and the Effective Number of Parties Index clearly indicates that in Albania predominates a Two party system which in the last elections have tended to become two and a half. This also confirms the presupposition that the only cleavage which shapes and structures the party system in Albania is the socio-economic one.

\section{Bibliography}

[1] Albanian Constitution (1998).

[2] Bartolini, S. dhe Mair, P. (2007) Identity, competition and electoral availability - the stabilization of european electorates 1885-1985, ECPR Press.

[3] Blondel, Jean. "Party Systems and Patterns of Government in Western Democracies." Canadian Journal of Political Science 1, no. 2 (1968): 180-203.

[4] Caplan, Constance and Alexander Knapp (1997) Technical Assistant Mission to the OSCE/ODHIR, Republic of Albania, May-July 1997, International Foundation for Electoral System: Washington.D.C. , Available at:

[5] http://www.ifes.org/ /media/Files/Publications/VRC/Reports/1997/R01506/R01506.p

[6] Central Elections Commission (2001) Rezultati Perfundimtar i Zgjedhjeve 2001 (Final Result of Parliamentary Elections 2001, Available at:

[7] http://cec.org.al/2004/eng/Zgjedhejekuvendfiles/rezultat2004.htm

[8] Central Elections Commission (2005) Rezultati i zgjedhjeve parlamentare sipas zonave, 2005 (The Result of Parliamentary Elections in constituencies), Available at:

[9] http://cec.org.al/2004/Zgjedhejekuvendfiles/Rez-zgjedhje2005/rezultatet\%20100\%20zona/buletini.htm

[10] Central Elections Commission (2005) Rezultati Perfundimtar i Zgjedhjeve Parlamentare, 2005 (Final Result of Parliamentary Elections, 2005). Available at: tvoteshttp://cec.org.al/2004/Zgjedhejekuvendfiles/Rezzgjedhje2005/rezultatet\%20vendore/linke/parti\%20rang\%20vendi.pdf

[11] Central Election Commission (2005) Perberja e kuvendit sipas subjekteve qe e mbeshtesin (Composition of the parliament). Available at:

[12] http://cec.org.al/2004/Zgjedhejekuvendfiles/Rezzgjedhje2005/rezultatet\%20vendore/linke/perberja\%20e\%20kuvendit_grafiku.pdf

[13] Duverger, Maurice, 1954 (1951). Political Parties: Their Organization and Activity in the Modern State. trans. by Barbara and Robert North. New York: Wiley. 
[14] Laakso, M. and R. Taagepera, 1979. "Effective Number of Parties: Measure with Appplication to West Europe." Comparative Political Studies 12: 3-27.

[15] Lane, Jan-Erik and Ersson, Svante (1994) Comparative Politics - An Introduction and New Approach. SAGE Publication.

[16] Lijphart, Arend, 1977. Democracy in Plural Societies. New Haven: Yale Press.

[17] Sartori, Giovanni (1976). Parties and Party Systems: A Framework for Analysis. Cambridge and New York: Cambridge University Press.

[18] Siaroff, Alan (2000). Comparative European Party systems: An Analysis of Parliamentary Elections Since 1945. New York: Garland Publishing.

[19] Siaroff, Alan (2003). "Two-And-A-Half-Party Systems and the Comparative Role of the 'Half"." Party Politics 9 , no. 3. 267-90. 